\title{
Wielding the Sword: President Xi's New Anti-Corruption Campaign
}

\author{
Fu Hualing*
}

\section{Introduction}

A state achieves legitimacy through multiple sources, one of which is the effectiveness of its governance. Generations of scholars since Hobbs have identified the maintenance of peace and order as core functions of a legitimate state. In the modern world, economic prosperity, social stability and effective control of corruption often provide adequate compensation for a deficit of democracy. Corruption closely correlates with legitimacy. While a perceived pervasive, endemic corruption undermines the legitimacy of a regime, a successful anti-corruption campaign can allow a regime to recover from a crisis of legitimacy. ${ }^{1}$

This is the rationale behind the periodical campaigns against corruption that have been conducted by the Chinese Communist Party ("Party"). ${ }^{2}$ Political leaders in China have found it expedient to use anti-corruption campaigns to remove their political foes, to rein in the bureaucracy and to restore public confidence in their ability to rule. Through anti-

\footnotetext{
*University of Hong Kong. An earlier version of this paper was presented at the Castle Conference on Global Corruption held at Yale University on May 1 and 2, 2014. The author would like to thank the participants for their comments on the paper and Michael West for his research assistance.

${ }^{1}$ Bruce Gilley, The Right to Rules: How State Win and Lose Legitimacy. New York: Columbia University Press, 2009; Mitchell Seligson and John Booth, The Legitimacy Puzzle: Political Support and Democracy in Latin America. New York: Cambridge University Press, 2009.

${ }^{2}$ Melanie Manion, Corruption by Design: Building Clean Government in Mainland China and Hong Kong. Cambridge, Mass.: Harvard University Press, 2004.
} 
corruption campaigns, emerging political leaders consolidate their political power, secure loyalty from political factions and regional political forces, and enhance their legitimacy in the eyes of the general public.

In an authoritarian state that experiences a high level of corruption, an anti-corruption campaign is a delicate political battle that addresses two significant concerns. The first concern is to orchestrate the campaign so that it is regime-reinforcing instead of regimeundermining. To remain credible, the regime must demonstrate its willingness and capacity to punish corrupt officials at the highest levels. Beyond rhetoric, there must be real, visible and convincing action that actually punishes some "tigers" - senior political officials. But at the same time, because corruption is deeply entrenched, wide-spread and an integral part of the governing system, overly rigorous anti-corruption law enforcement would necessarily target core supporters of the regime and, if allowed to be carried out to its full extent, may ultimately cause a significant defection of a substantial part of the supporters, which would undermine the regime.

A not unrelated dilemma relates to the transparency and publicity that is associated with credible anti-corruption law enforcement. Such enforcement must be carried out in the public domain and the people whose support is sought must be aware in order for a campaign to be credible. The authoritarian regime may not have a choice in the information age with more equality of access to information, moreover it is no longer feasible for an authoritarian regime to govern by controlling the flow of information. There is however an inherent tension between the imperative of disclosure and the imperative of secrecy. A meaningful disclosure of the degree of corruption within the Party may bring credibility to the campaign, however, it risks outraging instead of 
placating the general public. A full disclosure of the extent to which the Party is embroiled in corruption may invite further cynicism supporting the contention that the Party is irredeemably rotten to its core. An anti-corruption campaign, if not well-managed, may not only cause significant defection among core supporters of the regime but also generate further public anger and hostility toward the regime when the minutiae of corruption scandals are fully laid bare in the public domain.

A campaign that is not credible is unlikely to enhance the legitimacy of the regime; conversely, a credible campaign could ultimately threaten the regime's survival. Therefore, a regime-reinforcing campaign has to be highly selective and well-managed so that it will punish certain corruption officials while not undermining the regime. In President Xi's case, the anti-corruption campaign is necessarily instrumental and designed to serve the larger goal of his political and economic reforms.

The second political concern relates to the methods that are used in anti-corruption campaigns, including the institutions and actors upon which the campaign relies, and the procedures, if any, an authoritarian state uses. Because an anti-corruption campaign has to be regime-affirming, there unsurprisingly an authoritarian state tends to distrust institutions, actors and procedures with a strong democratizing potential that may pose a challenge to the regime in the long run. While authoritarian regimes like China's could develop the political will and capacity to combat corruption, such regimes fight corruption in ways that are congruent with the political system and rely on the concentration of political power and $a d$ hoc political mobilization outside existing legal institutions. If successful anti-corruption enforcement relies on effective external checks on political power, together with institutionalization and normalization of law 
enforcement based on a transparent rule of law, then the Chinese approach seems to be undermining the very institutions and designs upon which successful anti-corruption enforcement depends. Is China developing a sui generis model for anti-corruption enforcement?

This paper provides broadly outlines the political nature of the Party's anti-corruption campaign and the way in which corruption and anti-corruption are used as tools for the concentration of political power. It is divided into five parts. Following the introduction in Part 1, Part 2 touches on four potential objectives of the ongoing campaign that may benefit the $\mathrm{Xi}$ government. Part 3 discusses the process by which power is centralized in this anti-corruption campaign in terms of three relationships, namely centralization in the central-local relationship; centralization in the state-society relationship; and centralization in the relationship between political and legal institutions. Part 4 explores the possibility of an alternative Chinese model in anti-corruption enforcement. Part 5 is the conclusion.

\section{The Politics of Anti-corruption Enforcement}

The Chinese Communist Party (CCP) under Xi Jinping and Wang Qishan have launched an unprecedented anti-corruption campaign beginning in $2013 .{ }^{3}$ This is a sustained national campaign that targets both "tigers" (senior officials) and "flies" (low ranking bureaucrats) in the government and State-owned Enterprises (SOEs). The campaign is designed and led by the by the CCP, implemented through the CCP's disciplinary arm, especially the Central Disciplinary Inspection Committee (CDIC) under Wang's

\footnotetext{
${ }^{3}$ The CCP Central Committee, Establish a Sound System for Punishing and Preventing Corruption: A Work Plan 2013-2017 (建立健全惩治和预防腐败体系 2013-2017 年工作规划). http://news.xinhuanet.com/politics/2013-12/25/c_118708522_5.htm).
} 
leadership, targeting principally the Party officials. Xi's campaign resembles a Maoist campaign in several fundamental aspects ${ }^{4}$, the hallmark of which is powerful rhetoric, an effective decision-making process, swift and severe punishment and, above all, the marginalization of the rule of law and civil society. The current anti-corruption campaign builds on that legacy, reinforced the political dominance of the CCP in the anti-corruption process leading to an unprecedented concentration of political power in recent two decades.

The anti-corruption campaign is also a highly politicised process. The investigation is selective, politically motivated and aims to achieve particular political consequences. As China transitions to a post-revolutionary state, political leaders generally lack the necessary charisma and legitimacy to hold the country together. State power is increasingly fragmented and the central-local relationship in particular has become more delicate with local states openly or covertly asserting political powers. China's unitary state has been strained in the face of expansive local power, defined along political, economic or ethnic lines. Collective leadership in the absence of a cult of individual leadership has created a number of power bases without effective political and constitutional controls. Power may be centred on a policy area (e.g. Zhou Yongkang's monopoly over the political-legal system) or a region (e.g. Bo Xilai's control in Chongqing), further fragmenting the decision-making process.

A younger generation of authoritarian leaders in $21^{\text {st }}$ century China, who are ambitious to push through an aggressive reform agenda, needs to establish the political authority to

\footnotetext{
${ }^{4}$ For an analysis of Mao's long shadow over Xi, see, Joseph Fewsmith, "Mao's Shadow" http://media.hoover.org/sites/default/files/documents/CLMJF.pdf; Shai Oster, "President Xi's AntiCorruption Campaign Biggest since Mao.” Bloomberg, March 4, 2014.
} 
carry out reforms. Anti-corruption serves that objective well. Firstly, the campaign removes political foes in central ministries and regions. Xi's top-down anti-corruption enforcement is focused, surgical and in any event, well-managed, with a clear agenda of excising the empire of Zhou Yongkang. Most high profile detentions to date under Xi's leadership have been related to people who are directly or indirectly associated with Zhou. $^{5}$

Secondly, actual or potential political supporters are elevated to powerful positions. By removing political enemies, news leaders are able to create vacancies and thus place their supporters in powerful positions. In China's political system, a change of leadership at the top is not followed by a significant reshuffling of key positions. Because of deeply entrenched factional politics in China, it is more difficult for a new leader in China than it is in democracies to appoint a new team to positions of power in order to implement new policies. Facing with entrenched resistance, state leaders resort to alternative means, including anti-corruption enforcement, to create vacancies in political positions and reward their supporters with those positions. An anti-corruption campaign provides Xi with both sticks and carrots.

\footnotetext{
${ }^{5}$ They include 蒋洁敏, 王永春、李华林、冉新权, 王道富, 沈定成, all former or current members of the CNPC (中石油) and Shengli Oil Field (http://news.wenweipo.com/2014/02/22/IN1402220013.htm; 中石油一周 5 高管落马 反腐能否反出石油 亲民; for the on-going prosecution of Liang Jiemin, see http://news.sina.com.cn/c/2014-0410/115029903148.shtml); former personal secretaries, 李華林,沈定成，冀文林，郭永 祥; appointees in Sichuan including 李春城 (formerly deputy Party Secretary) 李崇禧 (formerly deputy Party Secretary), and 郭永祥(formerly executive deputy governor); representative in the public security including Li Dongsheng, deputy Minister of Public security ( http://www.open.com.hk/content.php?id=1642\#.UwhFrOOSy4k); and state security, including Liang Ke, Bureau Chief of the Beijing State Security B ure a u, (http://news.wenweipo.com/2014/02/22/IN1402220015.htm).
} 
Thirdly, Xi's anti-corruption campaign can reaffirm the political loyalty of powerful regional and sectoral leaders in provinces, ministries and SOEs. Anti-corruption enforcement is an entry point into the existing political system to ensure diverse political interests follow instructions from Beijing. As the Anti-Corruption Action Plan states clearly, one key objective of the anti-corruption campaign is to tighten up overall discipline within the Party so that the whole party is united in its thoughts and action under Xi's leadership. The "shock and awe" policy aims to send strong messages to stakeholders and monopoly interests that Xi can remove them if they are deemed disloyal. By using anti-corruption laws as a weapon, $\mathrm{Xi}$ can overcome possible obstacles created by entrenched interests in implementing his reform policies set out in the Third Plenum Resolutions. Politicians and bureaucrats may be deeply corrupt, but Xi has to rely on them to implement his reform plan. Deng Xiaoping initiated his reform in the late 1970s and bought bureaucrats' acquiescence to his reform agenda by allowing cadres to enrich themselves; Xi Jinping seeks to achieve his policy goal by threatening to take away everything that they have acquired over the past decades.

Finally, anti-corruption enforcement is instrumental in providing much needed legitimacy and credibility. ${ }^{6}$ The high profile campaign, particularly the wide spread investigation and quick removal of corrupt officials, demonstrates a strong anti-corruption political will and capability. Anti-corruption is extremely popular among the general public and in the private sector as wielding a sword of Damacles over the heads of senior leaders provides much needed legitimacy to Xi. Firm centralization of power, quick decision-making and

\footnotetext{
${ }^{6}$ Barry Naughton, "After the Third Plenum: Economic Reform Revival Moves toward Implementation," (2014) 43 China Leadership Monitor, http://media.hoover.org/sites/default/files/documents/CLM43BN.pdf
} 
effective top-down implementation characterizes the new campaign and in large part explains its popularity. Xi's sword has been sharp and merciless. Corruption, broadly defined to include any abuse of public power for private gains, has always been ranked as one of the top concerns facing the Chinese political system and once again proves prevalent, deeply embedded and entrenched in the political structure. There is a moral and political imperative for emerging leaders to launch anti-corruption campaigns. In a country with a revolutionary tradition and communitarian nostalgia which is facing unprecedented inequality and endemic corruption at the same time, the appeal of strongman anti-corruption campaigns is perhaps overwhelming to the masses and impossible to resist for ambitious leaders. Xi has seized the initiative, however, the real difficulty is not how to augment legitimacy through anti-corruption but how to manage public expectations.

\section{Recentralization through Anti-corruption}

Xi's anti-corruption campaign has witnessed a centralization of political power in general and the centralization of anti-corruption power in particular. Power steadily shifts towards the centre in three different ways. Firstly, Xi and Wang are re-designing the central-local relationship by transferring corruption investigation powers from provinces, ministries and SOEs to the Party's Central Committee for Disciplinary Inspection (CCDI), significantly reinforcing central control over regions within the Party structure. Secondly, the ongoing campaign relies on the Party's political machinery to the degree that it further marginalizes anti-corruption legal institutions. Under Xi's leadership, anticorruption has been reduced to an intra-party disciplinary matter. Third, while Xi is ruthless in grappling with high-level corruption, he is equally ruthless in clamping down 
on civil society mobilization against corruption. The censorship of critical voices on the Internet and the harassment and punishment of opinion leaders have been unprecedented, leading to a smothering of bottom-up mobilization against corruption.

Central control is secured through two mechanisms as decided by the Politburo on 27 August $2013 .^{7}$ The first mechanism is to further centralize the anti-corruption power in the hands of the CCDI and the second is to revitalize the central inspection system, which has been in place for nearly a decade and has not been effectively used.

The orthodox explanation is that the Party's disciplinary mechanism has failed to have an impact on corruption because of its lack of relational independence from local powers and in particular its dependence on the Standing Committee of the respective Party Committees, which it is expected to supervise and monitor. Local disciplinary officers are unwilling or unable to investigate local corruption seriously because of institutional design, local politics and social ties. In particular, the line of accountability within the Chinese political system has prevented local disciplinary officials from playing an active role in anti-corruption enforcement.

An essential part of the disciplinary system operates hierarchically and horizontally among three entities: the CCDI, the Provincial Party Committee and the provincial level disciplinary inspection committee (CDI). Horizontally, a CDI is in charge of anticorruption enforcement in the respective province and, as part of the Provincial Party Committee, is accoutable to the Provincial Party Committee. Hierarchically, a CDI is also accountable to the CCDI directly. Much of the controversy in anti-corruption

\footnotetext{
${ }^{7}$ 从同体监督到异体监.督.http://money.163.com/13/1021/01/9BM35OQR00253B0H.html
} 
enforcement in China relates to this dual, overlapping accountability; and key issues are whether a provincial CDI has been effectively captured by the Provincial Party Committee or whether the CCDI can exercise more effective central control over nationwide anti-corruption work.

The disciplinary system has been partially rejuvenated since 2005 when the CCDI and CDI were respectively authorized to dispatch a disciplinary official to be stationed in government departments and SOEs of the respective central and local levels. The intention was to create a degree of external supervision over government departments (异 体监督). For instance, the CCDI sends disciplinary officials to central ministries or SOEs directly under central control, and the dispatched disciplinary officials are directly accountable to the CCDI alone. However, the enforcement of this policy has not been effective. While the disciplinary official dispatched may be appointed by and accountable to the CCDI, he or she is often effectively co-opted by the government office which he or she supervises. The end result is that the supervisory system is effectively internalized and the system becomes largely self-regulatory (同体监督) leading to a near paralysis of the disciplinary system at the operational level. ${ }^{8}$

There have been pilot schemes to make CDI supervision more meaningfully independent of the government departments it supervises. For example, instead of sending one CDI head to be stationed in one government department, the CDI in Hubei province set up a supervisory office in 2009 in which a number of disciplinary officials jointly supervise eight provincial government departments without being stationed in any of those

\footnotetext{
${ }^{8}$ The failure is characterized as: “看得见的管不着, 管得着的看不见; 顶得住的站不住, 站得住的顶 不住; 干得好的上不去，上得去的干不好”纪检监察派驻机构改革:从“同体监督”到“异体监督” http://news.xinhuanet.com/politics/2010-04/06/c_1218383.htm
} 
departments. The objective of such a policy was to avoid cooption and to concentrate resources for more effective external supervision. ${ }^{9}$

A more difficult relationship that has not been effectively managed is the relationship between a CDI and the respective Party Committee, the crucial question being whether the CDI which supervises a Party Committee of the respective level is structurally part of the Committee or a supervisory body independent of the Committee? According to the CCP Charter, a CDI is a parallel body to the Party Committee and both are created by, and accountable, in theory, to it. The institutional design is such that the Party Committee at each level, being the organ of supreme political power, is watched closely by a disciplinary arm of the Party Congress.

But that design has been compromised by two institutional mechanisms that effectively reduce and marginalize the supervisory power of a CDI. According to the Party's personnel system, a higher Party Committee controls the appointment of key officials of a Party Committee at the next lower level. Significantly, all the officials with the rank of minister/provincial governor are placed on a central list and are accountable directly to the central authority. They are appointed, monitored and removed directly by the Ministry of Organization (MoO). Likewise, they are subject to the control of the CCDI for the purposes of disciplinary matters and anti-corruption investigation. ${ }^{10}$

An equally significant difficulty relates to the political practice which renders the CDI an integral part of the provincial political system. The structural rub is that the CDI head is

\footnotetext{
9纪检监察派驻机构改革:从“同体监督”到“异体监督” http://news.xinhuanet.com/politics/201004/06/c_1218383.htm

${ }^{10} \mathrm{Fu}$ Hualing, "The upward and downward spirals in China's anti-corruption enforcement," in Mike McConville and Eva Pils, (eds.) Comparative Perspectives on Criminal Justice in China (Edward Elgar, 2013), 390-410.
} 
also a member of the Provincial Party Committee standing committee and responsible to the committee. While the provincial CDI has been authorized to supervise the Provincial Party Committee including the Standing Committee members, the CDI operates within the institutional framework of the Provincial Party Committee and the political system places the CDI under the direct control of the Party Committee. Indeed, the disciplinary system directly places the provincial ranking officials directly under the CCDI control in anti-corruption investigations and the provincial CDI has no jurisdiction. ${ }^{11}$

To what degree does the CCDI control a provincial CDI in terms of appointment and operation? Since 2004, CCDI started to exercise the power to appoint the CDI head at the provincial level. ${ }^{12}$ But there is a degree of uncertainty. As stated above, since 1980 a provincial CDI was simultaneously accountable to both the Provincial Party committee and the CCDI.

In order to avoid cooption, the Party has adopted three related measures to enhance central control over the provincial level CDIs. The first is the restructuring of the CCDI to enhance its political and operation capacities; the second is to strengthen the control of CCDI over the provincial CDIs; and the third is to revamp ad hoc inspections of ministries, provinces and other central entities.

Under Wang Qishan's leadership, the CCDI created two bodies, an Organization Department and a Propaganda Department, to strengthen the overall personnel control and educational functions that are separate from, and independent to, the Party Committee. This serves to make a symbolic statement that, in terms of central-local

${ }^{11}$ 沈念祖, “十八大后 19 省部级高官落马:退居二线者和副职多”2014 年 01 月 04 日.

12 纪检体制改革拟破同体监督 http://www.bjnews.com.cn/feature/2013/11/08/291603.html 
relations, the CCDI is an independent system outside of the regular Party structure, which exercises independent political power. ${ }^{13}$ This is followed by the enhancement of the operational capacity of the CCDI in monitoring provincial level officials. The number of inspection offices (监察室) that carry out disciplinary inspection has been increased from eight to 12 so that there is a team of disciplinary officials in charge of monitoring high ranking officials in specific ministries or provinces. Even without an increase in the size of the CCDI, more than $100 \mathrm{CCDI}$ officials are said to have been reassigned to this operation. Those disciplinary officials do not only have the political power to monitor and control Party officials as the Party rules demand but also exercise legal powers, if necessary, through the support of police and the prosecution and courts to carry out interrogation, interception of communications, search, seizure or detention. The CCDI's power in anti-corruption investigation transcends institutional boundaries and is bound by no limits, except those imposed by the Party itself. ${ }^{14}$

The second strategy is to strengthen the CCDI control over the appointment of provincial CDI heads. The provincial CDI heads have always been dually accountable to the Provincial Party Committee and the CCDI and the current reform seems to tip the balance more decisively towards the CCDI. One mechanism is to parachute a CDI head to a sensitive region, such as the appointment of Hou Kai (侯凯), who was a core member of the CCDI and also a Deputy Auditor-General, as well as Shanghai's CDI head; or laterally transferred from other provinces, such as the appointment of Xu Songnan (徐松 南) as the CDI head of Chongqing. Xu was formerly the Organization Chief in Ningxia.

13 李永忠: 解读中纪委机构调整, http://www.21ccom.net/articles/zgyj/fzyj/article_20140418104617.html ${ }^{14}$ Mo Yitan, 官场公敌王岐山明镜出版社, 2014, Chapter 12. 
By January 2014, the heads of 21 provincial level CDI were appointed directly by the CCDI, including six from central ministries and 15 from other provinces. ${ }^{15}$ It is important to note that this practice of appointing a CDI head at a lower level directly by the CDI at the next higher level is long established. In that sense, although the current wave of parachute appointments and transferring provincial CDI heads may be unprecedented in terms of scale, it can also be seen as the continuation of a policy that has long been in existence.

Once a centrally appointed head is in place, there is more hands-on control over operational matters at the provincial level. The new rules provide that in conducting an anti-corruption investigation, investigative work should be placed principally under the leadership of a CDI at the next higher level and that reports to the Party Committee of the same level should also be sent to the CDI at the next higher level. Those new rules would necessarily create a more hierarchical disciplinary system with the CCDI at the centre and a clear intention to deprive the local Party Committee of exclusive control over anticorruption investigation at the equivalent local level. ${ }^{16}$

This second mechanism of central control has breathed life into the Central Inspection Groups (中央巡视组) (“CIG”) in which semi-retired high ranking officials are dispatched to provinces, ministries and SOEs for disciplinary inspection. CIG leaders are principally ministerial ranking officials who have retired from their frontline posts and are under the age of 70 years old at the time of appointment. There are exceptions. One of

\footnotetext{
${ }^{15}$ 中纪委首晒 4 个直辖市纪委架构: 一正四副成标配, http://news.sina.com.cn/c/2014-0127/130429358526.shtml

${ }^{16}$ 中纪委研究室: 有的地方案件频发追究责任不力 http://news.sina.com.cn/c/2014-0202/101629390680.shtml
} 
the exceptions is Hou Kai, Deputy Auditor-General of the National Auditing Authority, who headed the ninth CIG to inspect the Three Gorges Corporation.

This policy was designed in 1996 but did not come to fruition until 2003. It was organized by the CCDI and the Party's Ministry of Organization (MoO), and thus is referred to as the CCDI and $\mathrm{MoO}$ Inspection Group. In 2009, the CCID and MoO Inspection Group were renamed the Central Inspection Group to show case the group's status as an agent of the central committee of the $\mathrm{CCP}$ although the core members come from the CCID and MoO. Xi and Wang have effectively institutionalized the inspection system. ${ }^{17}$

The CIG's jurisdiction is broad and goes beyond corruption in the narrow sense. Officially, the CIGs are expected to focus on four issues in their inspection which are broadly defined to include bribery; collusion with business for self enrichment; extravagant life styles; and "political discipline" with a special focus on compliance with central policies and abuse in the appointment of officials.

The CIGs' work is divided into three stages during an inspection: discovering problems, reporting problems that are discovered and ensuring that proper action is to be taken to solve the problems. Since the CIGs do not have disciplinary powers, their principal function is to discover problems and to report their findings to proper authorities for action. To facilitate their inspection, the CIGs have three general powers exercisable in the course of inspection: 1) to receive reports, hear complaints, organize meetings, and conduct opinion surveys; 2) to organize meetings, visit officials, and review and copy

\footnotetext{
${ }^{17}$ For the background information of the third rounds of CIG inspection under the Xi government, see, http://www.ccdi.gov.cn/xwyw/201403/t20140315_20131.html
} 
documents; and 3) to conduct confidential interviews with individual officials of varying ranks. Throughout the four rounds of inspection to date, individual interviews are said to have been the most common and effective method of obtaining information. ${ }^{18}$ At the end of an inspection, the CIGs will report their significant findings to the central authorities. $\mathrm{Xi}$ and the entire politburo are debriefed by the CIGs.

Secondly, the CIGs report their findings on particular cases to relevant organizational or disciplinary authorities for action. The CCDI has undertaken to expedite cases that are referred to it by the CIGs. ${ }^{19}$ Each inspection has led to the down fall of a number of highranking officials in the respective provinces, ministries and enterprises. The CIGs are publically, specifically instructed to search for "tigers" and are warned clearly of the potential consequences of negligent investigations. Given the prevalence of corruption, the CIGs are not expected to return to Beijing empty-handed. Naturally, provinces which are to be inspected would experience tremendous consternation and anxiety until a "tiger" or two have been hunted down and punished. ${ }^{20}$ It is unknown whether the CIGs are actually finding new cases during their trips, gathering further evidence on existing cases or merely implementing decisions that have already made in a high profile manner. ${ }^{21}$ At least, according to Wang Qishan, the central authority is not surprised by the findings of the CIGs and corruption cases exposed by CIGs largely confirm the central government's suspicions. $^{22}$ After the two rounds of inspection in 2013, the CIGs passed their files to

\footnotetext{
18 中央巡视小组“打虎”记. How CIGS beating Tigers, http://www.infzm.com/content/98676.

${ }^{19}$ 中央巡视小组“打虎”记. How CIGS beating Tigers, http://www.infzm.com/content/98676.

${ }^{20} \mathrm{http} / / /$ news.qq.com/a/20130723/000658.htm

21 巡视组选择巡视地点有讲究相关线索或早被掌握, http//newsifeng.com/mainland/specia//annfivoontent3/detail_2014_01/09/32846004_0.shtml

22 王岐山:巡视发现的问题印证党中央对形势判断 http://news.sina.com.cn/c/2014-0315/164729715566.shtml
} 
the $\mathrm{CCID}$ and $\mathrm{MoO}$ leading to investigations into a number of vice-ministerial level officials.

Finally, the CIGs debrief the Party authorities of the provinces, ministries or other organizations inspected. Interestingly, in most debriefing sessions the CIGs are much more forceful and direct in criticizing the inspected departments than might have been expected. The Party secretaries of the provinces duly accept their findings, acknowledge shortcomings in its anti-corruption work and pledge to undertake the necessary action. The meetings, together with the problems that have been identified, are typically published on the front page of the provincial newspapers.

There are further procedural innovations differentiating the four rounds of central inspections from earlier practice. It has been emphasised that the CIG is only temporary and that each group created to carry out one particular inspection is disbanded immediately after the inspection. Group leaders and their deputies are also appointed on an ad hoc basis. The stated intention of this practice is to allow constant change of CIG leaders to avoid the inspectors being corrupted by local and sectoral interests.

There are highly targeted inspection and routine inspections, with the former focusing on specialist auditing of individual institutions. The key difference is that, while routine inspection aims at discovering corruption through inspection, targeted inspection is proactive investigation of corruption that is known to the CCDI. Targeted CIG inspection started in the third round of inspection and was conducted at the Ministry of Science and Technology, Fudan University and China National Cereals, Oils and Foodstuffs Corporation (COFCO). 
CIGs are given additional powers to carry out their inspection. CIGs are given powers to randomly check and verify personal records, especially financial records filed by provincial and ministerial leaders. This practice is not explicitly authorized by the Party's rules but is said to represent a new form of external accountability, indicating a possible shift from self-regulation to external accountability in the controversial area of asset disclosure.

The CIGs do not only investigate officials at the provincial level, during their inspection, but also create an environment so as to prompt local disciplinary inspection committees to take action. It is the clear intention of the CIGs to deter corruption at the provincial level creating a cascade effect throughout the Party. ${ }^{23}$ After the first round of CIG inspections, the CIGs were able to refer 25 cases involving ting/ju level officials and 26 cases involved $x i a n / c h u$ level officials to disciplinary committees to investigate and impose corresponding penalties. ${ }^{24}$ In this sense, the CIGs also aim to create a cascade effect on anti-corruption enforcement.

Through consolidating the leadership of the disciplinary inspection system at the provincial level and the CIGs, power is quietly but quickly shifted from provinces to Beijing. Indeed, Wang Qishan has specifically asked CIGs to serve as remote eyes (千里 眼) for the central authority to discover problems on behalf of the central authority and

\footnotetext{
${ }^{23}$ 王岐山在 2014 年中央巡视工作动员部署会上强调充分发挥巡视在党风廉政建设和反腐败斗争中 的作用. http://www.ccdi.gov.cn/xwtt/201403/t20140315_20129.html.

${ }^{24} 2013$ 年首轮中央巡视的地区、单位整改情况综述 http://www.ccdi.gov.cn/xwtt/201402/t20140228_19340.html
} 
report them faithfully to the central authority. ${ }^{25}$ In the process, provincial leaders are becoming the targets of anti-corruption investigation.

The primary function of the CIGs is not to overcome the agency problem but the loyalty problem. In the Chinese factional politics, the issue is not the lack of knowledge about what provincial leaders are up to. The central authority clearly has developed effective monitoring mechanisms for its provincial and ministerial level officials. The issue for emerging leaders is to ensure political loyalty from provincial and ministerial leaders and other subordinates. As an authoritarian state, in China the anti-corruption campaign and the periodic CIG inspections are serving that particular objective well.

\section{Raising Popular Support, Diminishing Public Participation}

A defining characteristic of the on-going anti-corruption campaign is not forceful topdown enforcement - China does not lack of top-down campaigns; instead, it is the diminishing public participation contrary to immense public support. The bottom-up anticorruption initiatives and mobilization which had been growing steadily are now severely restricted as the anti-corruption campaign progresses, and there is a steady decline in civil society participation and citizen involvement. People cheer largely on the sidelines. The new government suppresses civil society at the same time as it cracks down on corruption.

Before 2013 China had been developing a vibrant civil society aimed at exposing corruption through on-line mobilization and off-line action including legal action, political advocacy and street demonstrations. It is important to note that, while political forces from both the left and the right have a common anti-corruption agenda, it is those

\footnotetext{
${ }^{25}$ 揭秘中央巡视组: 当好中央"千里眼" 找出"老虎苍蝇"

http://news.china.com.cn/2013-06/06/content_29043286_2.htm
} 
on the right who are capable of taking actions. When this happens, anti-corruption becomes an integral part of a larger demand for political accountability and democratization.

Online anti-corruption mobilization has been a well-known phenomenon in China. Armed with information technology and the expanded realm of freedom, largely in a spontaneous fashion citizens gathered in virtual spaces to identify and hunt down corrupt officials through on-line mobilization.

Public opinions matter tremendously in China in the resolution of routine political and legal problems. Given the Party's democracy-deficit, its authoritarian leaders may be easily yield to public opinion and to appease public demands for further reforms. Within this particular context, it is not surprising to find that China has had an unusually active and vibrant online activism since the emergence of social media. Supported by the rapid evolution of information technology and a generally tolerant policy from the Party, Chinese netizens developed an aggressive culture of cyber activism to identify corrupt officials and expose corruption scandals through a coordinated search commonly referred to as "human flesh search" (HFS). ${ }^{26}$

The popularity of HFS may lead to its abuse. Anti-corruption is a forceful weapon for the government, which also acts as a useful resource in political competition, business dealing and getting revenge in personal and official matters. It is a resource that is being actively exploited and used in political and business competitions. Without strong

\footnotetext{
${ }^{26} \mathrm{Fu}$ Hualing, "Stability and anticorruption initiatives: is there a Chinese model?" in Susan Trevaskes, Elisa Nesossi, Sarah Biddulph and Flora Sapio (eds.) The Politics of Law and Stability in China (Edward Elgar, 2014). Yang, Guobin (2011), The Power of the Internet in China: Citizen Activism Online. New York: Columbia University Press.
} 
institutions and professional identity in China's political and legal institutions, public opinions in China can more easily swing decision-making and carry more weight than perhaps it ought. Once a potentially corrupt act is exposed and the perpetrators identified, an official investigation follows quickly and the Party soon imposes harsh and swift punishment without careful examination of the case involved. Gradually, on-line whistleblowing morphs into on-line vigilante justice. There are well-known cases in which aggrieved individuals posted allegations to expose corruption scandals leading to prompt investigation and official action. ${ }^{27}$

Anti-corruption mobilization and protests are not new to China. The 1989 democratic movement was in part an anti-corruption movement triggered by official profiteering. Corruption also casts a long shadow in some of the cases of high profile political unrest and public protest over so-called 'land-grabbing'. The Wukan protest, the longest and largest of its kind to date, was triggered by predatory land-grabbing in which corrupt local officials sold or leased village land without properly compensating villagers. However, since 1989 there has rarely been an overt concerted anti-corruption movement since the government has been sensitive to organized anti-corruption mobilization fearing that such a movement could easily morph into more widespread demonstrations calling for democratic reforms.

Critics and whistleblowers have also been effectively silenced using state laws. Defamation, both civil and criminal, from time to time has become a tool used by officials to silence whistle blowers. The former police chief of Chongqing who sought

\footnotetext{
${ }^{27}$ For a recent example, see 上海法官集体招嫖爆料者讲述跟踪举报始末 http://news.sina.com.cn/c/2013-08-10/021827911342.shtml
} 
protection in the US Consulate was infamous for authorizing the so-called double lawsuits (双起) in 2010 to encouraging defamation proceedings against a newspaper (by the police station) and a journalist (by police officers) ${ }^{28}$ After police pursuit of critical became so abusive, the national authorities briefly ordered caution and a stricter adherence of legal rules and procedures. ${ }^{29}$

Under the Xi government critics have been systematically silenced in two ways. The first is to target certain popular opinion leaders (the so-called Big V) and to use regular criminal laws to punish them. Well known cases include the prosecution of Charles Xue for visiting a prostitute; Wang Liming for disturbing public order, Dong Rubin (Bian Ming) (董如涁, 边民) for falsifying company registration capital, illegal business operations and disturbing public order; Qin Zhihui and Yang Xiuyu for slander and illegal business operations; Liu Hu for defamation; Zhou Lubao (周禄宝) for blackmailing and Chen Yongzhou for defamation. ${ }^{30}$ From the government's perspective, an "online pusher team", in collusion with opinions leaders and public intellectuals, creates a virtual "navy" to fabricate news, disturb public order, and undermine social stability. ${ }^{31}$ The chilling effect of a series of prosecutions is still being strongly felt in the virtual world and beyond.

\footnotetext{
28 公安局長的“雙起”讓輿論齒寒。

${ }^{29}$ For a review of the case law development, see Yan Meiling, "Criminal Defamation in the New Media Environment in the People's Republic of China," (2011) 14 International Journal of Communications Law and Policy 4-81.

${ }^{30}$ CHRD, A Nightmarish Year Under Xi Jinping's “Chinese Dream” http://chrdnet.com/wpcontent/uploads/2014/03/FINAL-PDF_2013_CHRD-Report-on-Human-Rights-Defenders-compressed.pdf .

${ }^{31}$ For a summary of the official view of the campaign, see, "The heavy fist must come out to deal with online rumor (written conversation)", http://chinacopyrightandmedia.wordpress.com/2013/08/31/theheavy-fist-must-come-out-to-deal-with-online-rumours-written-conversation/
} 
The second means of criminalizing speech online is to explicitly extend certain criminal offences to the virtual world, in particular through the offence of defamation by making and spreading rumors and disturbing public order. According to a resolution on judicial interpretation passed by the Supreme People's Court (SPC) and Supreme People's Procuratorate (SPP) in September 2013, ${ }^{32}$ a person can be convicted of defamation, resulting in a maximum penalty of three years imprisonment, if he or she creates and circulates rumors and the webpage posting these rumors have been visited by more than 5,000 internet users or reposted more than 500 times. The other significant change is an expansion in the scope of the public prosecution of defamation. Defamation depends principally on private prosecution and public prosecution is possible only when a case "seriously harms social order and state interest." ${ }^{33}$ The new interpretation provides a list of consequences which qualify for public prosecution and in doing so expands the armory for direct police intervention. ${ }^{34}$ In addition, the interpretation also creates a number of other online offences such as disturbing public order, online blackmailing, and online illegal business operation. While the police have been cautious in using the new law, the impact on internet activism and online mobilization, including HFS, is palpable.

Efforts have also been made to crackdown on off-line mobilization against corruption. The case of Xu Zhiyong and his New Citizens' Movement illustrates well the vigour of prosecution. Taking cues from Xi's declaration to "cage the power" and beat "flies" as

\footnotetext{
${ }^{32}$ SPC and SPP Interpretation on Several Problems in relation to the Application of Law in Handling Defamation and other Criminal Offences on the Internet (Judicial Interpretation 2013, No 21.

${ }^{33}$ Article 246 (2), The Criminal Law of People's Republic of China.

${ }^{34}$ Public prosecution is possible in the following circumstances where a case 1) has caused mass events; 2 ) has caused public disorder; 3 ) has caused ethnical or religious conflict; 4) has defamed a large number of persons and led to heinous social impact; 5) has harmed the state image and seriously endangered state interest; 6) has caused heinous international impact; or has caused other serious harm to social order and state interest. Article 3, Interpretation.
} 
well as "tigers" in a new round of anti-corruption campaigns, citizen activists massed under the banner of a New Citizens' Movement and the leadership of Xu Zhiyong to launch a series of public campaigns and street mobilization demanding the creation of a system which imposes a mandatory requirement for the Party and government officials to declare their personal assets. The clarion call received an initial positive response from the government. However, as the popular movement gathered momentum and shifted from online-campaigning to limited street action, the Party-State perceived the risk that an anti-corruption campaign may converge into a more broadly-based democratic movement. In response, the Party used criminal law to kybosh the movement. The conviction of Xu Zhiyong and his comrades in the New Citizens' Movement for disturbing public order, and the subsequent harassment of lawyers who defended the movement at trials, symbolizes a tragic end to a popular anti-corruption campaign.

The Xi government is committed to anti-corruption enforcement on the paramount condition of its monopoly over the entire process. At the same time, the Xi regime has launched the most systemic anti-corruption campaign to date. $\mathrm{Xi}$ is able to silence the social media and to diminish if not disable its anti-corruption functions by punishing opinion leaders, de-registering accounts and crippling civic activism by criminal punishment of the movement's leaders and activists. Xi may look to a "big society" in providing more cost-effective social services; however, bottom-up anti-corruption activism based on a vibrant civil society advocating social change is another matter altogether. ${ }^{35}$

\footnotetext{
${ }^{35}$ Tom Miller and Warren Lu, "Better Governance through Kung-Fu," GavekalDragonomics, February 14, 2014, www.gavekal.com.
} 


\section{Marginalizing Law}

Xi's campaign further shifts power from legal institutions to the Party's disciplinary mechanism. Compared with anti-corruption work under the previous government, the current campaign more decisively bypasses legal procedural and institutions. After a brief moment in which law seemed to be able to play a central role in the anti-corruption process, legal institutions have been effectively marginalized to the role of initiating anticorruption purges of "tigers". There is no longer any meaningful discussion on the end goals and limits of shuanggui, the Party's power to detain its own delinquent members as well as anti-corruption by a more neutral state body. Law may provide authority and legitimacy to support the Party's investigation but will emphatically not be tolerated as a hurdle to a concerted anti-corruption campaign. Indeed, the people who bitterly complain about the lack of credibility of anti-corruption investigations are the investigators in China's anti-corruption authority (ACA) (反贪污贿赂局), with the principal complaints being a lack of independence in initiating investigations and deference to the Party's inhouse disciplinary organ.

To be fair, the ACA has continued to deliver in the political circumstances it is constrained by. According to the national ACA director Xu Jinhui (徐进辉), the number of anti-corruption cases that the ACAs have investigated between January and November 2013 reached 27,236 involving 36,907 officials, representing an increase of $6.8 \%$ and $6.3 \%$ respectively. ${ }^{36}$ While the ACA was able to investigate 2257 xian/chu level officials during that period, in particular a few high profile investigations such as the cases against

\footnotetext{
${ }^{36}$ Interview with the Director of the National Anti-Corruption Authority. http://www.jcrb.com/talk/tjzft/xjh/index.html.
} 
Liu Tienan, Li Daqiu and Wang Suyi. Indeed the ACA's role and influence in the ongoing anti-corruption campaign as the national anti-corruption authority has actually declined under the new leadership.

There are a number of reasons legal institutions are not playing a more meaningful role in the current anti-corruption campaign. Firstly, the campaign is an integral part of a larger political rectification campaign of purges within the ranks of the Communist Party, with the ultimate aim to unite the Party under its new leadership. It is largely a political campaign by the Party and for the Party, which was initiated by the highest authority in the Party, carried out in accordance with the Party's internal rules and presided over principally by the Party's own organization and disciplinary authorities to entrench Xi's leadership. One of the principal goals of the CIGs is to identify and punish officials who openly defy important policies of the central authority.

Since anti-corruption investigation and disciplinary inspection are tools designed to serve political goals grounded on the shifting sands of political necessity, fixed rules and legal institutions are ill-fitted to play a leading role, if any at all. Pragmatic political calculations loom large in the the high profile cases and there is no place for legality or for that matter morality more broadly. ${ }^{37}$ During the earlier and most volatile stage of an anti-corruption campaign, the end of which is ultimately unpredictable, law takes a back seat at best.

The political nature of the campaign explains in part the extraordinary inertia of the SPP, which leads China's legal anti-corruption body. In accordance with its internal rules as

\footnotetext{
${ }^{37}$ Kerry Brown, "Xi Jinping Vs Zhou Yongkang," The Diplomat, 17 March 2014, http://thediplomat.com/2014/03/xi-jinping-vs-zhou-yongkang/
} 
outlined on the SPP website and in official news releases, strictly speaking the anticorruption storm that has swept up China techinically should not have happened at all. As an anti-corruption investigation body, the ACA's jurisdiction is narrowly defined and effectively limited to the investigation of actual crimes. This style of political campaign which has the appearance of casting a wide net without a specific target does not fall under the ACA's criminal investigation remit.

Secondly, the anti-corruption drive is taking place in the political stratosphere. It reaches the core of the Party's inner sanctum and aims in principal to rein in officials at the highest level. Given how legal institutions are configured in China's political system, ${ }^{38}$ they are simply not able to play a meaningful role. Under the Party rules, an investigation of a senior Party official and in particular a decision to detain or arrest must first be endorsed by the Party Committee at the respective level; and an investigation of corruption at the provincial or ministerial level necessarily requires the approval of, and action by, the central authorities. In practice, the statutory anti-corruption authority is more independent and capable of dealing with "flies" for the simple reason that the investigation would not require prior political approval. When the sights of the anticorruption guns were trained more keenly on those relatively minor officials, as in the past, the legal authority sometimes had a more meaningful role to play. Logically, when an anti-corruption campaign shifts principally to "tigers", the role of ACA is diminished immediately.

\footnotetext{
${ }^{38}$ Fu Hualing, "Autonomy, Courts and the Political-Legal Order in Contemporary China," in Cao Liqun, Ivan Sun and Bill Hebeton (eds.) Handbook of Chinese Criminology (Routledge, 2013), 76-88.
} 
Most of the ACA's investigations are limited to relatively minor corruption cases committed by junior officials. The ACA has concentrated its investigation on corruption that is related to, and reported by, ordinary people such as corruption in the process of land expropriation, school and university admissions, the provision of medical and health care, employment, public housing, social security, environment, food and drug safety, or poverty reduction. Such cases affect the daily lives of ordinary people and are of significant social concern, but are not on a grand scale. It is interesting to note that the tigers which ACA has investigated in the past year are isolated criminal cases that are not related to the Zhou Yongkang's network.

There are clear signs that, constitutionally, the Party is coming out more openly and forcefully to play a more visible and direct role in managing the society. The constitutional principle of Party leadership is deeply entrenched, although the Party prefers to hide in the shadows pulling strings to exert political influence through the government and other front organizations. Under Xi, the Party has become more conspicuous and more self-confident. The Party is more assertive in claiming its right to rule directly, bypassing legislative and executive authorities not to mention the judicial authority. ${ }^{39}$ While the Party looms increasingly large amidst the increasing marginalization of the legal process in relation to anti-corruption, the relevant legal rules no longer apply as they used to such as access to counsels, disclosure and transparency. Coupled with the silencing of social media and the narrowing of the public sphere in China in the immediate aftermath of the Xi take-over, anti-corruption enforcement is more opaque, more secretive and less rule-bound.

\footnotetext{
${ }^{39}$ Willy Lam, "New High-Level Groups Threaten Line between Party and Government," (2014) 14 (7) China Brief Volume.
} 


\section{A Chinese Model for Anti-Corruption Enforcement?}

Like generations of leaders before him, $\mathrm{Xi}$ initiated his campaign to enhance the popularity and legitimacy of the government and to pave the ground for his new policy initiatives, which raises questions of how much is new in this current campaign against corruption and to what degree are $\mathrm{Xi}$ and Wang able to break with the past?

Each Party Plenary Session seems to have triggered an intensive anti-corruption campaign on "tigers". The $15^{\text {th }}, 16^{\text {th }}, 17^{\text {th }}$ and $18^{\text {th }}$ plenary meeting took place in 1997 , 2002, 2007 and 2012 respectively and an anti-corruption campaign was initiated right after the meetings, leading to a large scale purge of Party members. The number of the Xi government may be more than 40 since he came to power and we may reasonably argue that the sheer size of punitive measures dealt out is also a significant departure. One may argue too that qualitatively Xi's campaign breaks new ground by investigating Zhou Yongkang, a former member of the Standing Committee of the Politburo, and a number of generals in the military. .

Another potentially significant departure is a much tighter and consistent control over direct or indirect public spending on the welfare of civil servants, especially the so-called sangong spending: in other words public spending on oversea travel, purchase and use of official cars and entertainment. The sangong spending is staggering and previous governments all tried to limit the spending with only limited success. ${ }^{40}$ The Xi government seems to have achieved more than any previous government in limiting

\footnotetext{
${ }^{40} \mathrm{http} / / /$ www.baike.com/wiki/\%E4\%B8\%89\%E5\%85\%AC\%E6\%B6\%88\%E8\%B4\%B9.
} 
government excess. The ambitious Eight Rules (八项规定) of the Party ${ }^{41}$ and the Three Measures (约法三章) of the State Council ${ }^{42}$ have the potential to significantly reduce waste from bureaucratic procedures when rigorously enforced. As usual, the Party is decisive in making new rules. By way of example the Three Measures require that, within the term of this government, there shall be no new government offices, no new recruitment of civil servants on government payrolls and no increase in sangong spending. This blunt instrument was apparently able to achieve its objective in the first year of the policy's implementation: conference spending and sangong spending by the central government was reduced by 53\% and 36\% respectively. Spending on entertainment in 31 provinces was reduced by $26 \%$. The objectives were achieved by imposing disciplinary action: more than 30,000 servants were investigated for violating the two sets of rules leading to 7,600 disciplinary sanctions. ${ }^{43}$

While Xi has demonstrated a strong determination and more forceful implementation, caution should be exercised not to exaggerate the success of measures adopted. The senior officials who have been investigated or punished belong to two categories. The first one is Xi's political enemies, the investigation of which is politically motivated and serves an express agenda. Judging by the profiles of the officials who fell from grace, they were primarily officials associated with his political nemesis, Zhou Yongkang, who are occupying important offices in security, Sichuan province, and oil fields. The purge of Zhou and his associates has been applied over the whole of Zhou's political career,

\footnotetext{
${ }^{41}$ http://fanfu.people.com.cn/GB/143349/353985/

42 坚持改进作风落实“约法三章”

http://news.xinhuanet.com/politics/2013-08/08/c_116862851.htm

43 持之以恒抓作风坚定不移反腐败——中央纪委副书记、监察部部长黄树贤答记者问. http://www.ccdi.gov.cn/xwtt/201403/t20140302_19413.html
} 
ensnaring his family members, protégés along with businessmen and officials who owed their success to, or had dealings with, him.

Beyond political enemies, Xi's other targets are mixed, but mainly officials who are semi-retired to the "second line" and no longer holders of real political powers. In point of fact, Xi may not really be after "tigers", but merely aims to punish officials who hold "second line" offices with high status but lacking political power, such as deputy chairmen of Provincial People's Congress Standing Committees or deputy chairmen of Provincial Political Consultative Conferences.

What is the best way to conceptualize Xi's anti-corruption campaign? It is widely recognized that while the heavy-handed top-down campaign may have a short-term deterrence impact on wide-spread corruption, it does not tackle the root causes which are arguably embedded in the political system. Wang Qishan has famously said that the anticorruption campaign does more harm to the Party as an organization than to the individuals under investigation. Removal of a larger number of senior officials produces a shock wave throughout the Party and it will take a long while for wounds to heal. The Party is prescribing tough medicine and shock therapy for corruption and the current campaign in many aspects is extremely destructive. The surgical operation that is ongoing and likely to be continuing for several years to come is not aimed at long term anticorruption capacity building. Again to quote Wang Qishan, the shock therapy is used to address the symptoms, that is to stop the further spreading and deepening of corruption and its intention is to buy time for $\mathrm{Xi}$ to tackle the root cause issues, that is to develop better institutional designs and improve the overall political accountability. 
How or even can the twin imperatives of the political need for short term impact and the long term goal of stamping out corruption be reconciled remains a tough question that has not been meaningfully debated or carefully researched. Perhaps inevitably the crackdown has to be selective given the prevalence of CCP corruption and the crude, ham-fisted approach is intended to achieve a goal that is broader than anti-corruption itself. As argued above, the anti-corruption campaign is orchestrated to eliminate Xi's political enemy and overcome real or potential resistance to Xi's reform agenda; legitimizing the new government and regain popular support; most significantly, Xi hopes, through force and discipline, to bring the bureaucracy on board. To do so, Xi needs political patronage and authority, and fighting corruption is an expedient tool to achieve this end.

There is an optimistic view that holds once the dust stirred up by the anti-corruption campaign has settled, Xi's government will turns its attention to institutional reforms, including political liberalization, further marketization of the economy and establishing robust anti-corruption institutions based on the rule of law, protection of property rights, freedom of the press and public participation. On the other hand, there is an equally persuasive expectation that Xi believes he can establish a Chinese model for fighting corruption, which relies on centralizing political power and ruthless, selective enforcement of Party rules. From this perspective, current and future anti-corruption strategies are likely to be predicated on a Party-centric, top-down approach in which a powerful Party-state, through a more effective internal disciplinary mechanism, controls Party members.

From the point of view of the latter, anti-corruption is a delicate political process that needs careful planning, coordination and management. Popular participation risks 
derailing the grand design. Public support should be solicited while public participation should be curtailed. Xi's and the CCDI's diagnosis assumes that anti-corruption enforcement is not effective because, in part, China lacks a centralized anti-corruption system that can coordinate anti-corruption work without interference in investigative work, which could operate responsibly to this end. ${ }^{44}$

Thus, the fundamental question remains as to what kind of institution can be established given the prevalence of corruption and deepness of public anger given the height of the expectations that have been raised? This boils down to how to control corruption without significantly eroding the monopoly of power by the Party at the same time as achieving his reform objectives?

At root, the choice is between an open control system and a closed control system. Best practice necessitates an open system which relies on political accountability, economic competition, effective protection of property rights, the freedom of speech, and a vibrant civil society. Translated into a Chinese context, the pivot point should be shifted gradually from the center to the local, from the Party to legal institutions and from the state to the civil society. On the other hand law and legal institutions in China are at present not powerful enough to rein in high-level corruption because of their inferior position in the overall political structure. In a country where law has not traditionally assumed an effective role, legal institutions cannot be relied on to deal with powerful political figures and in the absence of a will to give up power to the extent necessary to build effective institutions, only the Party is left to clean up the corruption of its own

\footnotetext{
${ }^{44}$ 中纪委研究室: 有的地方案件频发追究责任不力 http://news.sina.com.cn/c/2014-0202/101629390680.shtml
} 
members. To strengthen legal institutions would necessarily submit the Party to more legal control and carry certain political risks. Bottom up reforms may sound appealing but equally they can be chaotic and difficult to manage. Civil society mobilization carries even a higher political risk as organizations such as Xu Zhiyong's New Citizens' Movement could mutate into a fully-fledged movement for democracy.

The alternative is to opt for a closed system which depends on internal political control and Party discipline, together with enhanced communist morality, selfless dedication and commitment. ${ }^{45}$ Earlier generations of leaders struggled to square this circle and maintain a viable balance between open and closed systems, whereas $\mathrm{Xi}$ seems to have decided to shift the balance resolutely toward a closed system. Through strengthening the disciplinary system, especially direct central control over the disciplinary process and the further institutionalization of CIG inspections, Xi aims to rebuild the Party through an overall tightening of central control.

The Party talks much about external supervision and the risk of capture of internal supervision. However, the external supervision that the Party refers to is a very limited one. It merely calls for the further centralization of supervisory power in the hands of the central authority of the CCDI with Xi behind it. Ultimately the proposed reform posits further strengthening the Party as a whole at the cost of genuine external accountability. ${ }^{46}$ Having charted a particular course, different tools shall be experimented with the aim of achieving these objectives. Instead of learning from outside experiences, the Party is

\footnotetext{
45 习近平朗诵昔日填词《念奴娇-追思焦裕禄》 http://news.sina.com.cn/c/2014-03-19/073629741796.shtml 46 从同体监督到异体监督 http://money.163.com/13/1021/01/9BM35OQR00253B0H.html
} 
going back to Chinese historical roots to learn from emperors of dynasties who attempted to control their massive bureaucracy with limited means. In the end, $\mathrm{Xi}$ is trying to build a powerful and self-regulating Party, which is clean and benevolent, enjoys wide popular support, and is effective in controlling corruption. How he will move the Party Leviathan from its present to the future is highly uncertain.

\section{Conclusion}

Xi's anti-corruption campaign has witnessed an attempted re-concentration of political power that is unprecedented in recent years. Through designing new and shoring up old anti-corruption mechanisms, the anti-corruption campaign has sought to repatriate powers to the center in three ways. Firstly, there has been a shift of power from regional governments to the central government as demonstrated by CCDI's direct control of provincial CDIs in personnel and operation matters and by the high-profile CIGs that have been dispatched to a variety of provinces, ministries, universities and SOEs.

Secondly, power is further shifting from legal institutions to political institutions, particularly the Party's internal disciplinary system. The Party has repeatedly proclaimed its control over anti-corruption work; moreover, due to its top-down nature and a specific focus on senior ranking leaders, the current campaign largely bypasses existing legal procedures and legal institutions, leading to a further marginalization of the rule of law.

Finally, power is shifting from civil society back to the Party. President Xi proves equally harsh and effective in quashing corruption and civil society mobilization against corruption. In doing so, $\mathrm{Xi}$ is undermining the very institutions, such as the freedom of press or public participation, that may prove the most effective in reigning in corruption 
in the long run. In imposing a monopoly on China's anti-corruption enforcement, Xi has effectively silenced vocal critics bringing the social media practically to its knees through a series of repressive measures.

Of course, anti-corruption is a political necessity that is immensely popular. However, the campaign style as it has been carried out can hardly be sustainable, as top anti-corruption leaders such as Wang Qishan readily concede. To quote Wang, the Party is using the anticorruption campaign to buy the time that the Party needs to develop sound anticorruption institutions and tackle corruption at its root. ${ }^{47}$

That said, what the CCDI and the Party have in mind in terms of the design of more permanent anti-corruption institutions and what they understand as the root cause of corruption in China are far from clear. The Party has been struggling between internal regulation, self-regulation and external supervision in designing anti-corruption mechanisms for decades. Notwithstanding, external supervision has acquired a unique meaning in the PRC. Instead of relying on established institutions such as a separation of powers, media scrutiny, the rule of law and a vibrant civil society to supervise political power, the Party seeks a further concentration of power and relies on tougher disciplinary measures and sword-wielding enforcement. The current anti-corruption campaign moves decisively towards this direction.

\footnotetext{
${ }^{47}$ Wang Qishan, "The anti-corruption campaign should mainly deal with symptoms now in order to gain much-needed time to tackle the root cause in the future" (当前反腐要以治标为主 为治本赢得时间), January 25, 2013, http://china.caixin.com/2013-01-25/100486367.html.
} 